\title{
PERBEDAAN KEJADIAN DEPRESI PADA PASIEN CHRONIC KIDNEY DISEASE ON HEMODIALISIS YANG DIPENGARUHI DUKUNGAN KELUARGA
}

\author{
Yuliana Tina Mutiara', Wahyu Hidayati ${ }^{2}$, Ahmad Asyrofi $^{3}$ \\ ${ }^{1}$ Program Studi Ilmu Keperawatan Sekolah Tinggi Ilmu Kesehatan Kendal \\ ${ }^{2}$ Departemen Keperawatan Medikal Bedah Jurusan Keperawatan Universitas Diponegoro \\ ${ }^{3}$ Departemen Keperawatan Medikal Bedah Program Studi Ners Sekolah Tinggi lmu Kesehatan Kendal \\ Email: ahasyrofi@yahoo.co.id
}

\begin{abstract}
ABSTRAK
Penderita penyakit ginjal kronis (PGK) harus menjalani hemodialisa seumur hidup dan mengalami berbagai masalah akibat tidak berfungsinya ginjal yang dapat muncul setiap saat sampai akhir kehidupan. Keadaan ini menjadi stresor yang berpengaruh pada berbagai dimensi biopsikososiospiritual pasien seperti: ketidakberdayaan, kurangnya penerimaan diri yang dapat mengarahkan pasien pada kondisi stres, cemas, bahkan depresi. Tujuan penelitian ini untuk mengetahui perbedaan kejadian depresi antara pasien CKD on HD yang memperoleh dukungan keluarga baik dan kurang. Variabel penelitian ini meliputi variabel bebas dukungan keluarga variabel terikat depresi. Desain penelitian cross sectional. Populasi pasien CKD on HD dan jumlah sampel 40 pasien dengan teknik consecutive sampling. Hasil penelitian menggunakan fisher exact test menunjukkan perbedaan kejadian depresi pada pasien CKD on HD antara yang memperoleh dukungan keluarga baik dan kurang $(\mathrm{p}=0,021 ; \alpha=0,05)$. Rekomendasi, keluarga perlu memberikan meningkatkan dukungannya kepada pasien CKD on HD. Peneliti selanjutnya dapat melanjutkan investigasi tentang variabel lain yang mempengaruhi depresi pasien CKD on HD.
\end{abstract}

Kata Kunci : Penyakit ginjal kronik; dukungan keluarga; depresi; hemodialisa

\section{EFFECT OF APPLICATION OF GENERALIST NURSING ACTION: ANSIETAS ON CHRONIC POSTED DISEASE PATIENTS}

\begin{abstract}
Unhealthy lifestyle caused of chronic kidney disease. Urban communities are particularly vulnerable to unhealthy lifestyles, which can lead to chronic kidney disease. Chronic kidney disease is a condition which the kidney are permanently damaged and ultimately have an impact to the function of the kidney. Physical changes that occur in patients with chronic kidney disease associated with signs and symptom's the severity of the disease. It will certainly affect the psychosocial condition of patients. Psychosocial problems that arise in hopitalized patients with chronic kidney is anxiety. This Scientific works aims to describe the nursing care of anxiety in patients with Chronic Kidney disease especially with relaxation techniques. Patients who are able to overcome their anxiety will improve the effectiveness of the physical treatments that are being undertaken. Thus, the nurse's role in providing psychosocial nursing care is necessary so that anxiety problems do not cause adverse impact to the patient.
\end{abstract}

Keywords: Axiety, Chronic Kidney Disease, Relaxation technique

\section{PENDAHULUAN}

Data Amerika Serikat pada akhir tahun 2007 tercatat sebanyak 527.283 orang mendapat pengobatan penyakit ginjal tahap akhir (End Stage Renal Disease/ESRD) dimana 368.544 orang diantaranya mendapat terapi hemodialisis baik di rumah sakit, rumah maupun dialisis peritoneal (NKUDIC, 2010).Penyakit ginjal kronik merupakan penyakit sistemik yang terjadi ketika ginjal sudah tidak dapat mengangkut sampah atau melakukan fungsi regulasinya.Data dari Indonesian Renal Registry, suatu kegiatan registrasi dari Perhimpunan Nefrologi Indonesia,tahun 2008 jumlah pasien hemodialisismencapai 2260 orang.Pasien hemodialisis baru tahun 2008 naik menjadi 2260 orang dari 2148 orang pada tahun 2007 (Pernefri, 2007). Sekitar 70.000 penderita penyakit ginjal kronik yang memerlukan hemodialisis. Kasus penyakit ginjal di Jawa Tengah yang tertinggi adalah kota Surakarta 
1497 kasus $25.22 \%$ dan yang kedua adalah Kabupaten Sukoharjo yaitu 742 kasus $12.50 \%$ (Dinkes Jateng, 2008).Hasil Studi pendahuluandiRSUD Dr. H. Soewondo Kendal dalam 6 bulan terakhir terdapat 1228 pasien penyakit ginjal kronik, dan setiap harisekitar 10 pasien menjalani perawatan hemodialisa.

Terjadinya peningkatan jumlah pasien PGK stadium akhir tiap tahunnya, maka penggunaan mesin hemodialisa pun meningkat. Hemodialisa merupakan suatu proses yang digunakan pada pasien dalam keadaan sakit akut dan memerlukan terapi dialisis jangka pendek (beberapa hari hingga beberapa minggu) atau pasien dengan penyakit ginjal stadium akhir atau end stage renal disease (ESRD) yang memerlukan terapi jangkapanjang atau permanen (Suharyanto, 2009).Penderita penyakit ginjal kronis harus menjalani perawatan hemodialisa seumurhidupdan mengalami berbagai masalah yang timbul akibat tidak berfungsinya ginjal yang dapat muncul setiap saat sampai akhir kehidupan. Keadaan ini menjadi stresor yang dapat menimbulkan kelemahan fisik dan ketidakberdayaan serta kurangnya penerimaan diri, yang dapat mengarahkan pasien pada kondisi stres, cemas, bahkan depresi (Ratnawati, 2011).

Prevalensi depresi di Indonesia cukup tinggi sekitar 17-27\%, sedangkan di dunia diperkirakan 5-10\% pertahun. Data WHO menyebutkan bahwa pada tahun 2020, depresi akan menjadi beban global penyakit kedua didunia setelah penyakit jantung iskemik. Di Indonesia, prevalensi depresi pada pasien penyakit ginjak kronik (PGK) yang menjalani hemodialisa mencapai $31,1 \%$ dan sebagian besar komponen kualitas hidup mereka lebih rendah dari pada yang tidak mengalami depresi (Wijaya, 2005).

Depresi dapat dikurangi dengan memberikan dukungan oleh keluarga pada pasien hemodialisa. Dukungan keluarga merupakan dukungan yang diberikan oleh anggota keluargayang membantu individu untuk mengatasi masalah pasien. Seseorang yang mendapat dukungan emosional dan fungsional terbukti lebih sehat dari pada individu yang tidak mendapat dukungan (Suprajitno, 2004).Dukungan keluarga ini dapat berbentuk dukungan instrumental, informasional, penilaian, dan emosional (Marrelli, 2008 \& Prasetyawati, 2011).Dukungan sosial akan semakin dibutuhkan pada saat seseorang sedang menghadapi masalah atau sakit (Efendi, 2009).Dukungan untuk orang dengan penyakit ginjal kronikbisa berupa dukungan instrumental, dukungan informasional, dukungan penilaian, dan dukungan emosional(Prasetyawati, 2011).Tujuan penelitian ini untuk mengetahui perbedaankejadian depresi pada pasien CKD on hemodialisis yang dipengaruhi oleh dukungan keluarga.

\section{METODE}

Penelitian ini terdiri dari variabel bebasdan terikat. Variabel bebasnya adalah dukungan keluarga dan variabel terikatnya adalah tingkat depresi pasien hemodialisa. Hipotesisnya adalah terdapat perbedaan depresi antara klien CKD on HD yang memperoleh dukungan keluarga dan tidak. Desain penelitian cross sectional.Populasi penelitian ini adalah pasien yang sedang menjalani hemodialisa di ruang Hemodialisa RSUD Dr. H. Soewondo Kendal. Sampel penelitian yaitu klien yang menjalani program hemodialisasebanyak 45 pasien.Teknik pengambilan sampel Consecutif sampling. Kriteria inklusinya: 1) Menjalani terapi hemodialisa 1-2 kali dalam 1 minggu. Alat penelitian untuk mengukur dukungan keluarga menggunakan kuesionerMOS Social Support Survey, teori keperawatan keluarga dan penelitian sebelumnya. Skoring kuesioner MOS Social Supprot Survey menggunakan skala Guttman, jika jawaban ya skor: 2 dan jika tidak skor: 1 . Hasil ukur variabel jika skor $<62,08$, maka dukungan kurang, dan jika skor $\geq 62,08$, maka dukungan baik(Friedman, 2010 \& Damayanti, 2013). Kuesioner depresi menggunakan kuesioner HRS-D (Hamilton Rating Scale for depresion) terdiri dari 21 kelompok gejala, masing-masing kelompok gejala diberi penilian antara 0-4 dengan penilaian sebagai berikut: nilai 0 : tidak ada gejala atau keluhan, nilai 1: gejala ringan, nilai 2: gejala ringan, nilai 3: gejala berat dan nilai 4; gejala berat sekali. Hasil skoring depresi yaitu: 17: tidak ada depresi, 18-24: depresi ringan , 25-34: depresi sedang, 35-51: depresi berat dan 52-68: depresi berat sekali. Pengumpulan data primer langsung diperoleh dari subjek penelitian dengan menggunakan alat pengukuran. Instrumen penelitian telah dilakukan uji validitas isi dengan cara meminta pendapat dari ahli (judgement expert). Hasil uji validitas konstruk (uji coba 20 responden) 
diperoleh nilai pearson product moment 0,601 $-0,789$ ( $\mathrm{r}$ tabel $>0,444)$, sehingga semua butir dinyatakan valid.Hasil realibilitas diperoleh nilai alpha cronbach 0,756 yang artinya reliabel.Analisis data dilakukan secara univariate dan bivariat. Analisis univariat menggunakan tendency central, variasi, dan proporsi, sedangkan analisis bivariat menggunakan Fisher's Exact Tets dengan signifikansi 0,05 .Etika penelitian ini meliputi: informed consent, anonymity dan confidensiality.

\section{HASIL}

Hasil penelitian menunjukkan rerata umur pasien CKD 47 tahun dengan standar deviasi 9 tahun. Jenis kelamin $52,5 \%$ perempuan, pendidikan terbanyak lulusan SD 27,5\%, sebagian besar pasien menjalani HD lebih dari 1 tahun (52,2\%). Analisis fisher exact test menunjukkan perbedaan signifikan kejadian depresi pasien $\mathrm{CK}$ on HD diantara yeng memperoleh dukungan baik dan dukungan kurang ( $\mathrm{p}=0,021 ; \alpha=0,05$ ). Pasien CKD on HD yang memperoleh dukungan keluarga kurang baik sebanyak $47,5 \%$ dan sebanyak $85 \%$ pasien CKD on HD mengalami depresi. Informasi selengkapnya dipaparkan tabel di bawah ini.

Tabel 1.

Deskripsi Usia pasien CKD $(\mathrm{n}=40)$

\begin{tabular}{cccccc}
\hline Variabel & Mean & Median & SD & Min - Maks & CI 95\% \\
\hline Umur & 47,08 & 46,50 & 9,197 & $25-69$ & $44,13-50,02$ \\
\hline
\end{tabular}

Tabel 2.

Deskripsi Jenis Kelamin, Pendidikan, dan Lama Hemodialisa pasien CKD n=40)

\begin{tabular}{|c|c|c|}
\hline Variabel & Frekuensi & Persentase \\
\hline \multicolumn{3}{|l|}{ Jenis Kelamin } \\
\hline Laki-laki & 19 & 47,5 \\
\hline Perempuan & 21 & 52,5 \\
\hline \multicolumn{3}{|l|}{ Pendidikan } \\
\hline Tidak sekolah & 6 & 15,0 \\
\hline $\mathrm{SD} / \mathrm{MI}$ & 11 & 27,5 \\
\hline SMP/MTs & 9 & 22,5 \\
\hline SMA/MA & 8 & 20,0 \\
\hline Perguruan tinggi & 6 & 15,0 \\
\hline \multicolumn{3}{|l|}{ Lama menjalani HD } \\
\hline Bulan & 12 & 30,0 \\
\hline Lebih dari 6 bulan & 7 & 17,5 \\
\hline Lebih dari 1 tahun & 21 & 52,2 \\
\hline
\end{tabular}

Tabel 3.

Deskripsi Dukungan Keluarga dan Tingkat Depresi Klien CKD $(n=40)$

\begin{tabular}{|c|c|c|}
\hline Variabel & Frekuensi & Persentase \\
\hline \multicolumn{3}{|l|}{ Dukungan Keluarga } \\
\hline Dukungan baik & 21 & 52,5 \\
\hline Dukungan kurang & 19 & 47,5 \\
\hline \multicolumn{3}{|l|}{ Tingkat depresi } \\
\hline Tidak depresi & 6 & 15,0 \\
\hline Depresi ringan & 6 & 15,0 \\
\hline Depresi sedang & 13 & 32,5 \\
\hline Depresi berat & 15 & 37,5 \\
\hline
\end{tabular}


Tabel 4.

Perbedaan kejadian depresi pasien CKD on HD yang memperoleh dukungan keluarga baik dan kurang $(\mathrm{n}=40)$

\begin{tabular}{|c|c|c|c|c|}
\hline \multirow{2}{*}{ Dukungan keluarga } & \multicolumn{2}{|c|}{ Depresi } & \multirow{2}{*}{ Total } & \multirow{2}{*}{$P$ value } \\
\hline & Depresi & Tidak Depresi & & \\
\hline Dukungan Kurang & $19(100 \%)$ & $0(0 \%)$ & $19(100 \%)$ & \\
\hline Dukungan Baik & $15(71,4 \%)$ & $6(28,6 \%)$ & $21(100 \%)$ & 0,021 \\
\hline Total & $34(85 \%)$ & $6(15 \%)$ & $40(100 \%$ & \\
\hline
\end{tabular}

\section{PEMBAHASAN}

Hasil penelitian menunjukkan terdapat perbedaan kejadian depresi pada pasien CKD on HD yang memperoleh dukungan keluarga baik dan kurang.Beberapa bukti ilmiah menunjukkan bahwa pemberian dukungan individu untuk melihat segi-segi positif yang ada dalam dirinya dibandingkan dengan orang lain, yang berfungsi untuk menambah kepercayaan diri dan kemampuan serta merasa dihargai dan berguna saat individu mengalami masalah atau tekanan (Nursalam, 2009).Sebagian besar dukungan keluarga baik, hal ini menunjukkan bahwa dukungan keluarga pada pasien CKD on HD menggunakan penilaian positif dan dorongan untuk maju sehingga pasien dapat merasa tenang, diperhatikan, timbul rasa percaya diri dan kompeten. Dukungan keluargamendorong pasien PGK memiliki semangat yang tinggi untuk bertahan hidup.

Dukungan keluarga dapat berupa bantuan yang nyata atau tingkah laku yang diberikan oleh orang yang dekat dengan subjek, atau berupa kehadiran dan hal yang dapat memberikan keuntungan emosional atau pengaruh pada tingkah laku penerimanya. Dukungan keluarga juga berperan penting dalam pengelolaan berbagai jenis penyakit kronis termasuk PGK. Dukungan keluarga berpengaruh pada psikologisseseorang, individu yang menghadapi persoalan merasa dirinya tidak menanggung beban sendiri dan masih ada orang lain yang memperhatikan, mau mendengar keluh kesah, bersimpati, dan empati terhadap persoalan yang dihadapinya, bahkan mau membantu memecahkan masalah yang sedang dihadapi(Setiadi, 2010).

Depresi merupakan gangguan alam perasaan (mood) yang ditandai dengan kemurungan dan kesedihan yang mendalam dan berkelanjutan sehingga hilangnya gairah hidup, tidak mengalami gangguan dalam menilai realitas (reality testing abiity), kepribadian tetap utuh atau tidak mengalami keretakan kepribadian (Splitting of personality), perilaku dapat terganggu tetapi dalam batas-batas normal (Hawari, 2013).Depresi bisa terjadi akibat perasaan stres yang berat akibat tuntutan kehidupan, rasa sedih yang dalam dan menyakitkan dan bisa disertai rasa bersalah dan mengasihani diri sendiri. Hubungan depresi dan mortalitas yang tinggi juga terdapat pasien-pasien yang menjalani hemodialisis jangka panjang. Kondisi afeksi yang negatif pada pasien penyakit ginjal kronik juga seringkali bertumpang tindih gejalanya dengan gejala-gejala pasien penyakit ginjal kronik yang mengalami uremia seperti iritabilitas, gangguan kognitif, encefalopati, akibat pengobatan atau akibat hemodialisis yang kurang maksimal (Cukor, 2007 \& Chen, 2010).

Depresi juga dipengaruhi oleh faktor-faktor seperti kondisi kesehatan, trauma, perubahan dan tekanan hidup, emosi, harga diri dan yang lainnya. Kondisi kesehatan seperti penyakit gagal ginjal kronik ini sangat berpengaruh terhadap psikologis pasien tersebut, ini menjadikan pasien ginjal merasa tertekan, kehilangan semangat dalam menjalankan aktivitas, kehilangan pekerjaan dan memiliki pikiran-pikiran negatif tentang kehidupan yang akan dijalani kedepannya. Ketakutan dan perasaan berduka juga kerap datang karena harus tergantung dengan alat cuci darah seumur hidupnya.

Depresi juga dapat ditimbulkan dari diri sendiri maupun dari luar, seperti halnya timbul akibat tuntutan pekerjaan atau beban yang terlalu berat, kondisi keuangan, ketidakpuasan dengan fisik, penyakit yang dialami, masa pubertas, karakteristik atau sifat yang dimiliki dan sebagainya. Faktor dari luar dapat bersumber dari keluarga, masyarakat, dan lingkungan. Depresi pada penyakit ginjal kronik bisa terjadi akibat tekanan dari 
lingkungan, kehilangan pekerjaan maupun perubahan peran di keluarga, untuk mempertahankan hidupnya manusia senantiasa berusaha untuk menghindari stres yang ada dalam hidupnya.

Terdapat perbedaan kejadian depresi yang dipengaruhi oleh dukungankeluarga pasien CKD on hemodialisa. Dukungan sosial sebagai adanya kenyamanan, perhatian, penghargaan atau menolong orang dengan sikap menerima kondisinya, dukungan sosial tersebut diperoleh dari individu maupun kelompok. Pasien yang mendapatkan dukungan sosial keluarga yang positif atau sesuai dengan kebutuhan pasien maka dapat menurunkan depresi pasien gagal ginjal tersebut tetapi karena dukungan sosial yang dirasakan pasien tersebut adalah negatif maka keadaan tersebut tidak dapat menurunkan depresi pada pasien gagal ginjal yang menjalani hemodialisis sehingga sebagian besar pasien berada pada depresi berat.

Dukungan sosial keluarga terhadap tingkat depresi sangat berpengaruh dalam psikologis seseorang ketika seseorang mengalami masalah dalam kehidupannya. Sistem pendukung seperti keluarga, teman, dan rekan kerja yang akan mendengarkan dan memberikan nasihat dan dukungan emosional akan bermanfaat bagi seseorang yang mengalami depresi. Sistem pendukung dapat mengurangi reaksi depresi dan meningkatkan kesejahteraan fisik dan mental.

Individu dengan dukungan sosial tinggi pada pasien penyakit ginjal akan mengurangi tingkat depresi, dan juga dengan melakukan koping yang lebih baik, selain itu dukungan sosial dari keluarga juga memiliki hubungan dengan penyesuaian yang baik untuk proses pemulihan yang lebih cepat dari penyakit ginjal kronik. Individu yang berada pada suatu kondisi yang berdaya sangat membutuhkan dukungan dari orang-orang yang berada didekatkannya.

Dukungan sosial keluarga juga mempunyai hubungan positif yang dapat mempengaruhi kesehatan dan kesejahteraan atau dapat meningkatkan kreativitas indivividu dalam kemampuan penyesuaian yang adaptif terhadap depresi dan rasa sakit yang dialami. Keadaan yang sangat depresi juga dapat mengganggu kemampuan individu untuk menggunakan dukungan sosial secara efektif sehingga keadaan seperti itu membangkitkan dan menciptakan konflik bagi seseorang yang memberikan dukungan dapat mengancam dukungan sosial yang ada.

Perbedaan individu dalam bereaksi terhadap stresor tergantung berbagi faktor seperti harapan akan self-efficacy, ketahanan psikologis, dukungan sosial, dan optimis individu dalam menghadapi depresi yang ada. Setiap orang mempunyai persepsi dan respons yang unik terhadap masalah yang dihadapi, persepsi seseorang terhadap stresor didasarkan pada keyakinan dan norma, pengalaman dan pola hidup, faktor lingkungan, struktur dan fungsi keluarga, tahap perkembangan, pengalaman masa lalu dengan depresi, dan mekanisme koping. Sehingga ketika pasien mendapatkan dukungan sosial yang positif atau sesuai dengan kebutuhan pasien maka dapat menurunkan depresi pasien gagal ginjal tersebut tetapi karena dukungan sosial yang dirasakan pasien tersebut adalah negatif maka keadaan tersebut tidak dapat menurunkan depresi pada pasien gagal ginjal yang menjalani hemodialisis sehingga sebagian besar pasien berada pada depresi berat.

Hubungan dukungan sosial keluarga dengan tingkat depresi sangat berpengaruh, karena dukungan yang diperoleh individu dari keluarga membantu individu untuk melihat segi-segi positif yang ada dalam dirinya dibandingkan dengan orang lain yang berfungsi untuk menambah kepercayaan diri dan kemampuan karena mendapatkan kasih sayang, kepedulian, perhatian dari orang terdekat sehingga menumbuhkan rasa kepercayaan diri dan kondisi psikis yang baik.Depresi yang terjadi pada pasien gagal ginjal kronis yang menjalani terapi hemodialisa merupakan konsekuensi lanjut dari ketidak berhasilan pasien dalam mengenali dan mengatasi stressor psikososial yang dialaminya(Chilcot et al, 2008). Dukungan yang diperoleh individu dari keluarga berupa penilaian positif dan dorongan untuk maju.

Hasil dari analisa di atas menunjukkan masih banyaknya pasien hemodialisa dengan dukungan baik juga masih merasakan depresi ini karena setiap individu memiliki cara koping tersendiri untuk mengatasi masalah yang 
sedang dirasakan apabila seseorang mengalami distres karena tidak mampu menghadapi stres berat sehingga mengalami depresi yang melebihi kemampuan individu untuk berubah.

\section{SIMPULAN DAN SARAN}

\section{Simpulan}

Hasil penelitian dapat disimpulkan bahwa terdapat perbedaan signifikan kejadian depresi antara pasien CKD on HD yang memperoleh dukungan kurang dan dukungan baik.

\section{Saran}

Peneliti merokemendasikan kepada keluarga untuk memberikan dukungan terbaik meliputi: moral, material, informasi dan lainnya untuk pasien agar pasien selalu merasa diperhatikan, disayangi, dicintai, dan dimengerti akan kondisi yang dialaminya. Bagi peneliti selanjutnya dapat meneliti variabel lain yang mempengaruhi kejadian depresi pada pasien CKD on HD.

\section{DAFTAR PUSTAKA}

Chen CK, Tsai YC, Hsu HJ, Wu IW, Sun CY, Chou CC, et al. (2010). in Depression and Suicide Risk in Hemodialysis Patients With Chronic Renal Failure. Psychosomatics 51:528-528.e6

Cukor D, Coplan J, Brown C, Friedman S, Cromwell-Smith A, Peterson RA, Kimmel PL. In Depression and Anxiety in Urban Hemodialysis Patients.Clin J Am Soc Nephrol 2007; 2: 484-490

Davison, G.C., Neale, J \& Kring,A. (2006). Psikologi abnormal. Edisi ke -9. Jakarta: PT Raja Grafindo Persada.

Chilcot, J., Wellsted, D., Silva-Gane, M.D., and Farrington, K.. (2008). Depression on Dialysis. Nephron Clin Pract 108: c256-c264.

Hawari, D. (2013). Manajemen Stres Cemas dan Depresi. Jakarta: Badan penerbit FKUI.

Lubis, A. J. (2006). Dukungan Sosial pada Gagal Ginjal Terminal yang Melakukan Terapi Hemodialisa. Sumatera: USU Repository.
Lukman, et al. (2013). Hubungan Tindakan Hemodialisa Dengan Tingkat Depresi Klien Penyakit Ginjal Kronik di BLU RSUP PROF. DR.R.D. Kandou. Ejournal Keperawatan(e-kep), 1(1).1.

Maurus, J. (2009). Mengenali dan Mengatasi Depresi. Jakarta: Rumpun

Nursalam, \& Baticaca, F. (2009). Asuahan Keperawatanpada Pasien dengan Gangguan Sistem Perkemihan. Jakarta: Salemba Medika.

Perdana, H H. (2011). Studi deskriptif Kecemasan pada pasien yang menjalani hemodialisa. Kendal.

Pernefri. (2007). Data Penyakit Ginjal di Indonesia.diakses tanggal 23 september 2013 pukul 10.00 WIB.

Prasetyawati, A E. (2011). Ilmu Kesehatan Masyarakat untuk Kebidanan Holistik. Yogyakarta: Nuha Medika.

Ratnawati. (2011). Tingkat Kecemasan pasien dengan Tindakan Hemodialisa di BLUD RSU DR. M. M DUNDA Kabupaten Gorontalo. Jurnal Health \& Sport,Vol. 3 , Nomer 2.

Suharyanto, T. (2009). Asuhan Keperawatan pada Klien dengan Gangguan Sistem Perkemihan. Jakarta: CV. Trans Info Media.

Wijaya. A. (2005). Kualitas Hidup Pasien Penyakit Ginjal Kronik Yang Menjalani Hemodialisa Dan Mengalami Depresi. Jakarta: Fakultas Kedokteran Unversitas Indonesia. 